\section{IJ§ER}

ISSN: 2149-5939
International Journal of Social Sciences and Education Research

Online, http://dergipark.gov.tr/ijsser

Volume: 3(2), 2017

\title{
Job satisfaction in terms of social gender equality in employees and its effect on the corporate reputation: The sample of ERU academicians
}

Emel Tanyeri Mazıcl ${ }^{1}$

Received Date: $01 / 09$ / 2016

\author{
Kürşad Gölgeli²
}

Accepted Date: 15 / $01 / 2017$

\begin{abstract}
Corporate reputation consists of the total of emotions, opinions and perceptions of all the shareholders of the institution. Company employees, who has an important place within these shareholders also play an effective role in success and continuity of the company by being affected from the activities, directly or indirectly. At this point, in the forming of the emotions, opinions and perceptions of employees, job satisfaction that is achieved in time has the key importance. Thus, the employees who are the internal shareholders contribute to the corporate reputation through job satisfaction. In this study, job satisfaction, which is created via the effect of many variables, is evaluated through "social gender equality". Such that, gender equality and how the company carries this variable will contribute to the corporate reputation by differing positively in the trust in the company, sense of justice and job satisfaction of the employees. In the Erciyes University Example, which is found in the application part of the study, perceptions of academicians, who are a profession group that have an important place in society, on corporate reputation and job satisfaction levels will be analyzed through social gender equality by survey scanning as an empirical method and some evaluation and suggestions will be made.
\end{abstract}

Keywords: Social gender equality, job satisfaction, corporate reputation, academic employees

\section{Introduction}

The concept of Corporate Reputation has recently gained crucial importance in that it creates an abstract value for the continuity of corporations and companies. In this regard, reputation is comprised of all perceptions about a company which is maintained in the long run as a guarantee of its existence and credibility in the market. It is possible to describe the value of reputation, which could be attained in the long run, through several variables. Among these variables, the employees of a company have a different place as the closest shareholders and the dynamo of internal communication. In this respect, the views of employees about their jobs and their satisfaction have crucial impact not only on their own performance and improvement but also for the vision and reputation of the company. We could speak of different factors providing job satisfaction on the part of employees. These factors are directly connected with the running of company, its atmosphere, aurora and business flow. An item of recent researches and close interest in literature and agenda, the concept of social gender could have a direct impact on job satisfaction given the perceptions and assessments it specifically creates on the part of individuals. Job satisfaction of employees in a corporation, where gender discrimination is thought to exist, could be directly impacted with this idea. In this sense, the study analyzes job satisfaction, which is an important concept affecting corporate reputation, and social gender, as a variable comprising job satisfaction, to create a specific evaluation. In that sense, universities are the only institutions that could form an originating point for critical and free opinion as well as ensuring its dissemination. The

\footnotetext{
${ }^{1}$ Erciyes University, Kayseri, TURKEY, emeltanyerimazici@gmail.com

${ }^{2}$ Erciyes University, Kayseri, TURKEY, kgolgeli@hotmail.com
} 
Tanyeri Mazıc1, E., Gölgeli, K. (2017). Job satisfaction in terms of social gender equality in employees and its effect on the corporate reputation: The sample of ERU academicians. International Journal of Social Sciences and Education Research, 3(2), 508-518.

study deals with the social gender perceptions of academicians recruited in the university in regards to their job satisfaction and the connection of this perception with corporate reputation. As a quantitative method, surveys are conducted on 174 academicians working at Erciyes University and then some deductions are made from this analysis.

\section{Conceptual framework and definitions for relevant variables}

The study includes job satisfaction of employees as an important variable influencing corporate reputation. It is certainly possible to mention a number of factors affecting job satisfaction of employees. In this sense, the study specifically analyzes employees' perception of social gender in the company they work as one of the factors providing job satisfaction. To this end, the conceptual framework will include "corporate reputation", "job satisfaction" and "perception of social gender" inter-connectedly.

\subsection{The concept of corporate reputation}

Today, modern corporations are interested in the way they are perceived by society. Perception could be defined as the methods used for selection, filtering, organizing and interpretation of inputs from society while the concept of image could be defined as the perception about individuals and corporations and/or institutions. As a result of direct and indirect perceptions and experiences, there forms a corporate image in the minds of people (Sabuncuoğlu, 2004, p. 65-66). All messages coming from the company or corporation have an impact on the corporate image and in return the path to be followed by reputation is formed (Peltekoğlu, 2009, p. 589-592). The ideas of value and trust formed as a result of positive observations and experiences obtained in the past could be defined as reputation. Reputation is included in the non-physical values of a corporation or institution. Similarly, today the corporate reputation of companies is taken as the predictive factor rather than taking their physical assets when evaluating their corporate or institutional values.

Fombrun (1996) describes corporate reputation as a perceptual representation of a company's previous actions and future views that describe the firm's appeal to all of its key components.

Corporate reputation is regarded as the "the total added value of trust of a company in the total market value" (Kadıbeşegil, 2013, p. 59). Corporate value could be defined as the concise view of all perceptions of a company's shareholders. In other words, it is the beliefs of a company's employees, customers, suppliers, managers, financers, media and community about what it is and their attachment to the company (Chun, 2005, p. 105).

In order to describe the role of managing corporate reputation, it's necessary to look into the concepts of corporate brand and image. A corporate brand determines what a company or corporation wants to be and how it could attain this goal. Its aim is to reinforce the motivation of all shareholder groups in order to attain corporate objectives. In essence, the corporate brand is established by the company and in parallel a corresponding image and reputation is indirectly perceived by the shareholders of a corporation or company. While corporate image represents the instant vision of an individual, corporate reputation is rather a more stable perception (Gobbers \& Storck, 2011, p. 28-29). Reputation is so important for a company to be able to attract new employees and investors. In addition, it is of crucial importance for having an impact on strategical marketing options like more friendly process costs and ratings (Camara, 2011, p. 49-50). 
Tanyeri Mazıcı, E., Gölgeli, K. (2017). Job satisfaction in terms of social gender equality in employees and its effect on the corporate reputation: The sample of ERU academicians. International Journal of Social Sciences and Education Research, 3(2), 508-518.

When the correlation and differentiation between corporate reputation and other concepts are conducted, it will be observed that corporate identity (total symbols) has an impact on corporate image (perceptions about the corporation), corporate image has an impact on corporate reputation which is the view and judgement of shareholders, and finally corporate reputation has an impact on corporate reputation capital (the economic assets of a corporation) (Barnett et al., 2006, p. 33).

The main factors playing a role in the formation and reinforcement of corporate reputation could be listed as product quality, financial performance, innovation, consumer, media and quality of human resources (Fombrun \& van Riel 2003). At this point, the most important groups affecting reputation are customers and employees. Specifically, the job satisfaction of employees has a very important place at this point. Likewise, job satisfaction could be defined as the indicator of the pleasure obtained from the job. There are two important factors affecting job satisfaction. These are what employees think about their jobs and the attitudes of managers about human relations. Job satisfaction of employees is one of the organizational objectives (Türk, 2007, p. 70-71). Human resources department is responsible for ensuring that employees have a feeling of trust about the organization in which they work and they feel pleased with the working environment, while public relations department is responsible for ensuring that there is a communicative bridge between corporate management and employees (Akdağ, 2010, p. 83). It is one of the widely acknowledged realities that a corporation should have effective communication with their employees in order to promote corporate productivity, to maintain total quality and to establish a positive image thus forming a corporate reputation (Peltekoğlu, 2009, p. 516).

\subsection{The concept of job satisfaction as a factor with an impact on corporate reputation}

Employee satisfaction and effective internal communication are not only crucially important internal dynamics effecting corporate performance, but they are also of significance for the formation and utilization of corporate reputation. The concept of job satisfaction which is coined as "job satisfaction" in English Literature stands for the general total of the attitudes of employees towards their work and workplaces (Eren, 1998, p. 178). Referring to the viewpoint of an employee to his/her job (Robbins \& Judge, 2012, p. 43), this concept is an important variable both for the employee satisfaction and for corporate reputation. Co-workers in a company, equal and fair management approach and supportive practices are some of the important factors affecting job satisfaction. Apart from these, gender differences could be regarded as one of discriminant factors causing different levels of job satisfaction among workers. For instance; Savery and Luks (2000, p. 307-308) stated that men are more tolerant towards corporate initiatives demanding long work hours, while women are more interested in part-time jobs, flexible work hours and short working periods during the week because of their responsibilities like house-work and child care (as cited in Negiz et.al., p. 2011:210).

It is clarified in some empirical studies that job satisfaction has a positive impact on corporate reputation (Çekmecelioğlu \& Dinçer, 2013, p. 131). In this respect, the path that goes to corporate reputation passes from employee satisfaction and job satisfaction and requires that the perception of social gender in the corporation, as one of the factors ensuring relevant satisfactions, should be an objective and maintained among employees at an acceptable level. The perception of a company on the part of target groups formed by employees has an impact on the corporation itself. By this way, employees could establish strong relations with customers. 
Tanyeri Mazıc1, E., Gölgeli, K. (2017). Job satisfaction in terms of social gender equality in employees and its effect on the corporate reputation: The sample of ERU academicians. International Journal of Social Sciences and Education Research, 3(2), 508-518.

It is the employees who come face to face with consumers, potential customers and suppliers and for this reason the impression of employees on their counterparts has an impact on corporate reputation. By the same token, employees take the first place in significance in the formation and maintenance of corporate reputation. Due to the influence of employees on corporate reputation, the studies analyzing and scaling corporate reputation focus on social opportunities and rights provided to employees, payment policies and employee satisfaction (Baybora, 2011, p. 120). Similarly, several researches indicate that there are various factors affecting job satisfaction. It is possible to gather them in two groups as individual factors and corporate factors. Age, gender, education, marital status, personality etc. could be listed as individual factors, while payment, promotion opportunities, co-workers, management and work environment etc. comprise corporate factors (Serinkan \& Bardakç1, 2007). In this respect, the study will analyze perceptions of social gender as a concept with an impact on both individual and corporate levels.

\subsection{The concept of social gender as a factor affecting job satisfaction}

As a concept, gender has an aspect that signifies the genetically, biological and physical differences (Marshall, 2005, p. 98) between individuals. The term gender not only forms the distinguishing factor in the fields of medicine, genetics, and biology, but it can also function as a demographically distinguishing factor in researches in the field of social sciences. Whether or not there is a significant difference between the female viewpoint towards events and phenomena and that of male also highlight the transformation of such a biological difference has been exposed within the social culture and society. It is such that the concept of gender, given by nature and coined as the social gender, can attain different roles and responsibilities under the influence of society and culture (Giddens, 2005, p.108-109).

Individuals learn their female and male gender roles and behaviors throughout a socialization and acquisition process starting in the family and continuing with education life, media, social environment (Connell, 1998, p. 165-167). This issue, as a concept, generally seems to be associated with or involving just women, however males also have roles, responsibilities and perceptions within the society.

This concept, which has been valid throughout the history of humankind, has been the subject of researches in different ways throughout history. In addition to the researches and theories on the basic level, we could also speak of a large number more specific researches focusing on social gender and equality (Oakley, 1998), social gender and division of labour (Reed 2003), social gender and science (Keller, 2007). In relevant field works, the concept of social gender and gender perceptions could be analyzed from the viewpoints of various sectors and work groups (Kocacik \& Gökkaya, 2005; Kahraman et.al., 2014; Dursun et.al., 2013). For instance in the theories like glass ceiling syndrome and velvet ghetto women are found to be rather recruited on the mid and low level professions undertaking technical roles, while men, although low in number, are assigned to administrative roles on senior level positions authorized with taking strategical decisions specifically in the field of public relations (Hon et al., 2005). Even this example alone sets out the realistic picture regarding career development, distribution of authorization and responsibility.

By the same token, the approaches of employees to their workplace based on their perception of social gender have a crucial place among factors affecting organizational devotion and job satisfaction of employees in a corporation or company. Some titles among these studies including 
Tanyeri Mazıcı, E., Gölgeli, K. (2017). Job satisfaction in terms of social gender equality in employees and its effect on the corporate reputation: The sample of ERU academicians. International Journal of Social Sciences and Education Research, 3(2), 508-518.

allocation of authorities and responsibilities, training and professional development, employment, improving in terms of career, payment, benefitting from social rights and risks of harassment or mobbing (http://www.tisk.org.tr) could bear in vocational life. This unbalanced allocation could bear direct outcomes on the feelings and opinions of an employee towards his/her workplace thus impairing his/her work performance.

According to "Gender Equality National Action Plan 2008-2013", while the number of female workers is relatively low in our country, the fact that the number is a lot lower when it comes to administrative positions thus necessitating a series of actions (National Action Plan, 2008, p. 48). Although the number of female academicians is high, they are rather employed in positions like research assistants, instructors. The rate of senior positions for female academicians such as deans and rectors is quite low (the rate of female rectors 5,3\% and that of female deans is $12,6 \%$ ) (National Action Plan, 2008, p. 49). In this context, there is a Women's Issues Research and Implementation Center supported by 15 different universities in Turkey and there are Women's Studies Departments at 4 universities. Important steps are taken at universities to raise awareness about this issue (National Action Plan, 2008, p. 23).

The studies dealing with the social gender perceptions of academicians (Kahraman et.al. 2014; Dursun et.al. 2013; Poyraz 2013; Özkaplan 2012) include relevant data representing the perceptions of academicians affiliated with various universities. When relevant data are considered in general, the following assumptions about job satisfaction could be made that there are significant differences between genders in terms of job satisfaction, males rather gather upon deeply-rooted customs and traditional viewpoints and glass ceilings are still valid for females especially in regards to career development and acquisition of administrative positions.

\section{Methodology}

\subsection{Research theme, importance and objective}

The study focuses on social gender perceptions, which is one of the large number of factors providing job satisfaction for employees, as a determinant variable for corporate reputation. The study deals with and analyses the impact of these perceptions on job satisfaction and indirectly on corporate image over the case of Erciyes university academicians.

The relevant perception at universities as the centers of scholarly and scientific works is of unique importance as it sets the ground for the fundamentals and outlook for social gender perceptions, and this might well provide a good reason for this study. Specifically, for the relative importance of the study, the perception at universities, which are the centers of free and critical views and scientific knowledge, is of crucial importance as it sets the groundwork for the viewpoint to and outlook for social gender. As several the essence of concepts like free and critical thinking, equality and fair management and social development are laid and promoted at universities, the social gender perceptions of academicians is an important determinant variable as they associate the job satisfaction they experience with the reputation of their institution. In addition, the data to be obtained in this study will prove important in that they might allow us to make comparisons between the findings of previous studies conducted at various universities and to analyze the process of development and transformation. 
Tanyeri Mazıcı, E., Gölgeli, K. (2017). Job satisfaction in terms of social gender equality in employees and its effect on the corporate reputation: The sample of ERU academicians. International Journal of Social Sciences and Education Research, 3(2), 508-518.

The study aims to analyze the impact of job satisfaction by analyzing and evaluating the viewpoints of academicians (workers) about the reputation of their institution. In this respect, there seems to be multiple factors affecting job satisfaction of workers. The study will specifically analyze the social gender perceptions of academicians thus revealing its impacts on institutional reputation.

In order to analyze and evaluate corporate reputation over the variables of job satisfaction and social gender, the research uses survey conduction, one of the quantitative research methods, for data collection. The initial periods of the study is characterized with the identification of research questions, definition of problem, creating a draft survey form through deductions from current studies and expert views, development of pilot implementation form, and giving its final shape to the survey form by making necessary additions and removals (Büyüköztürk et.al. 2010:127). The first stage includes data collection from the literature, classification, analysis and interpretation. Then, the final shape of the survey form is given by adopting the scales of Kahraman et.al. 2014; Turban and Cable 2003. The survey form is initially tested on a population of 30 people and some parts of the form are re-designed to eliminate misunderstandings. Later, the Cronbach Alpha value of the survey form is analyzed to obtain a value of 0,768 which let us to further our study. The agreement levels of participants regarding some questions referring to demographical data (gender, marital status, academic titre) as well as to social gender perceptions, how these perceptions are reflected in job satisfaction and its correlation with corporate reputation could be listed as (5 I totally agree; 4 I agree; 3 I'm neutral; 2 I disagree; 1 I totally disagree) over the Likert Scale and some deductions are made accordingly. The study also has frequency analyses and Mann Whitney $\mathrm{U}$ analyses to bear a series of deductions.

\subsection{Research model, sample and hypotheses}

The research model is illustrated in Figure 1. Hypotheses are identified over this model and then findings are analyzed and interpreted.

Figure 1. Research model

\begin{tabular}{|c|}
\hline Perception of Social Gender \\
\hline$\downarrow$ \\
\hline Job Satisfaction \\
\hline$\downarrow$ \\
\hline Corporate Reputation \\
\hline
\end{tabular}

The population of research includes the academicians working at Erciyes University. As a result of data obtained from the Academic database relevant to the sample, it is observed that there are totally 2751 academicians with 1110 of them $(\% 40,35)$ being females and the remaining $1641(\% 59,65)$ males. In the light of this information, a survey has been conducted on 200 academicians with a reliability level of $95 \%$ and 7 deviation rate and when the survey forms including wrong coding were left out, 174 survey forms were subject to analysis.

The general question of the research includes the question whether the perception of social gender has an impact on the job satisfaction of employees thus on corporate reputation or not. In this context, the research questions could be listed as below: 
Tanyeri Mazıcı, E., Gölgeli, K. (2017). Job satisfaction in terms of social gender equality in employees and its effect on the corporate reputation: The sample of ERU academicians. International Journal of Social Sciences and Education Research, 3(2), 508-518.

Question 1: Is there a significant correlation between corporate reputation and job satisfaction?

Question 2: Is there a significant correlation between job satisfaction and social gender?

Question 3: Are there significant differences between the perceptions of female and male workers about social gender and view of corporation?

\section{Research findings and evaluation}

Given the demographical data the following deductions could be made; $65,3 \%$ of participants are males, while $34,7 \%$ are females. $34,7 \%$ of them have been recruited in relevant institution for more than 11 and more years. $23,1 \%$ have worked for $6-10$ years, $39,9 \%$ for $1-5$ years while $2,3 \%$ have worked for less than one year. $60 \%$ of participants are married, while $30,8 \%$ are single. When academic titles of participants are analyzed, 7,6\% are professors, 13,5\% are Associate Professors, 20,5\% are Assistant Professors, 11,1\% are lecturers; 42,1\% are research assistants, 4,1\% are instructors and finally $1,2 \%$ are recruited as experts. A distribution has been made over the rates of intensity in accordance with a proportionate approach based on the number of academicians at each faculty.

The rate of those thinking that women are more advantageous in work life is $11 \%$, while the rate of those on the side of men is $35,5 \%$ and that of those thinking that gender is not important is $55,5 \%$

Given the frequency of agreements (f\%) about relevant judgments in Table 1, there seems to a positive impression in general and there is low agreement level for well-established assumptions. Participants agreed with the statements "I think that the tasks I undertake are appropriate to my education, capabilities and skills." $(54,6)$, "My workload is just at necessary level." and I think that there is a balance between my tasks and my authority." $(48,6)$, "I feel an attachment to my workplace and I am honored to work here.", "I think that the senior management attaches importance to the views and suggestions of employees." (42,2), "I think there is a fair and equal distribution of social opportunities among employees in my workplace." $(38,2)$, "I think there is a fair and equal distribution of tasks."(34,7), "In general, this workplace has a positive image in my view." (51,2), "I experience job satisfaction in this workplace.” $(48,0)$, "My administrators don't make gender discrimination among employees." $(42,8)$, "There is no gender discrimination in recruitments in my institution." $(41,6)$, "There is no gender discrimination in promotions in my work place." (45,1), "My job satisfaction is negatively influenced by gender discrimination in the work place.” $(43,6)$.

The highest rate of total agreement has been demonstrated for the statement "Gender discrimination has an impact on corporate reputation." $(43,9)$, while that of Total Disagreement was for "If the economic power of a man is enough, it is better that the woman does not work."(34,3), "It is the man's fundamental duty to make a living for the house.." $(28,9)$.

The statements which participants Disagreed are as follows "Gender is an important factor in task distribution in my workplace." (37,0), "Gender should be an effective factor in task distribution in the work place." $(37,6)$, "It is generally necessary to make a difference between tasks as "men's job" and "woman's job" in professions and corporations." $(34,7)$ and "I think that women and men are given equal opportunities in society. "( 38,4$)$. 
Tanyeri Mazıc1, E., Gölgeli, K. (2017). Job satisfaction in terms of social gender equality in employees and its effect on the corporate reputation: The sample of ERU academicians. International Journal of Social Sciences and Education Research, 3(2), 508-518.

Table 1. Statements about reputation, job satisfaction and social gender variables

\begin{tabular}{|c|c|c|c|c|c|}
\hline & $\begin{array}{l}\text { I totally } \\
\text { agree }\end{array}$ & I agree & $\begin{array}{l}\text { I am } \\
\text { neutral }\end{array}$ & $\begin{array}{l}\text { I don't } \\
\text { agree }\end{array}$ & $\begin{array}{l}\text { I totally } \\
\text { don't } \\
\text { agree }\end{array}$ \\
\hline $\begin{array}{l}\text { I think that the tasks I undertake are appropriate to } \\
\text { my education, capabilities and skills. }\end{array}$ & 27,0 & 54,6 & 12,6 & 3,4 & 1,1 \\
\hline My workload is just at necessary level. & 12,7 & 48,6 & 12,7 & 22,0 & 4,0 \\
\hline $\begin{array}{l}\text { I think that there is a balance between my tasks and } \\
\text { my authority. }\end{array}$ & 10,4 & 48,6 & 23,7 & 14,5 & 2,9 \\
\hline $\begin{array}{l}\text { I feel an attachment to my workplace and I am hon- } \\
\text { ored to work here. }\end{array}$ & 37,6 & 42,2 & 12,7 & 4,6 & 2,3 \\
\hline $\begin{array}{l}\text { I think that the senior management attaches im- } \\
\text { portance to the views and suggestions of employees. }\end{array}$ & 11,6 & 42,2 & 25,4 & 15,0 & 5,8 \\
\hline $\begin{array}{l}\text { I think there is a fair and equal distribution of social } \\
\text { opportunities among employees in my workplace }\end{array}$ & 11,6 & 38,2 & 28,9 & 15,0 & 5,8 \\
\hline I think there is a fair and equal distribution of tasks. & 10,4 & 34,7 & 29,5 & 19,7 & 5,8 \\
\hline $\begin{array}{l}\text { In general, this workplace has a positive image in my } \\
\text { view. }\end{array}$ & 22,7 & 51,2 & 18,0 & 7,6 & - \\
\hline I experience job satisfaction in this workplace. & 21,4 & 48,0 & 20,2 & 7,5 & 1,7 \\
\hline $\begin{array}{l}\text { My administrators don't make gender discrimination } \\
\text { among employees. }\end{array}$ & 23,7 & 42,8 & 18,5 & 13,9 &, 6 \\
\hline $\begin{array}{l}\text { There is no gender discrimination in recruitments in } \\
\text { my institution. }\end{array}$ & 20,2 & 41,6 & 23,1 & 13,9 & 6 \\
\hline $\begin{array}{l}\text { Gender is an important factor in task distribution in } \\
\text { my workplace. }\end{array}$ & 6,4 & 23,7 & 26,6 & 37,0 & 5,8 \\
\hline $\begin{array}{l}\text { There is no gender discrimination in promotions in } \\
\text { my work place. }\end{array}$ & 24,9 & 45,1 & 15,6 & 11,6 & 2,3 \\
\hline $\begin{array}{l}\text { My job satisfaction is negatively influenced by gen- } \\
\text { der discrimination in the work place. }\end{array}$ & 38,4 & 43,6 & 10,5 & 5,8 & 1,7 \\
\hline $\begin{array}{l}\text { Gender discrimination has an impact on corporate } \\
\text { reputation. }\end{array}$ & 43,9 & 42,8 & 6,9 & 5,8 & ,6 \\
\hline $\begin{array}{l}\text { Gender should be an effective factor in task distribu- } \\
\text { tion in the work place. }\end{array}$ & 4,0 & 11,0 & & 37,6 & 31,2 \\
\hline $\begin{array}{l}\text { It is generally necessary to make a difference be- } \\
\text { tween tasks as "men's job" and "woman's job" in } \\
\text { professions and corporations. }\end{array}$ & 2,3 & 9,8 & 21,4 & 34,7 & 31,8 \\
\hline $\begin{array}{l}\text { I think that women and men are given equal opportu- } \\
\text { nities in society. }\end{array}$ & 5,8 & 16,3 & 21,5 & 38,4 & 18,0 \\
\hline $\begin{array}{l}\text { If the economic power of the man is enough, it is bet- } \\
\text { ter that the woman does not work. }\end{array}$ & 4,7 & 12,2 & 16,3 & 32,6 & 34,3 \\
\hline $\begin{array}{l}\text { The professions that could a woman do should be dif- } \\
\text { ferent from those of woman's. }\end{array}$ & 4,0 & 13,3 & 24,9 & 32,4 & 25,4 \\
\hline $\begin{array}{l}\text { It is the man's fundamental duty to make a living for } \\
\text { the house. }\end{array}$ & 11,6 & 17,9 & 13,3 & 28,3 & 28,9 \\
\hline
\end{tabular}

Given these data, participants might be said to have taken positive stances regarding taskauthoritiy distribution, feeling of attachment to the workplace, job satisfaction and positive image of the workplace, no gender discrimination in recruitments and promotions, the existence of which would have a negative impact on job satisfaction. There has been a high rate of approval for statement indicating total agreement with the fact that gender discrimination would have a negative impact on institutional/corporate reputation.

There has been a high of disagreement for the statements indicating that gender is an important factor in distribution of tasks, there should be a difference like women's jobs and men's jobs, women and men have equal opportunities in society. Participants demonstrated total disagreement for the statement indicating that it's the man's duty to make a living for the house. 
Tanyeri Mazıcı, E., Gölgeli, K. (2017). Job satisfaction in terms of social gender equality in employees and its effect on the corporate reputation: The sample of ERU academicians. International Journal of Social Sciences and Education Research, 3(2), 508-518.

As for the research questions, it is revealed that there is a significant and linear correlation between corporate reputation and job satisfaction in the first question, as well as indicating that the higher the job satisfaction is the higher the corporate reputation would get; the second question bears a significant and linear correlation between job satisfaction and social gender equality. While positive social gender perceptions would have a positive impact on and increase job satisfaction and there will be a corresponding decrease in the opposite case.

As for the agreement levels regarding the third research question, it is observed that there is a significant difference between female and male participants. In this regard, the two independent groups are compared through Mann Whitney $U$ test. It is revealed that there are significant differences for 7 statements (Asymp-sig $<0,05$ ).

These statements are; "I think that there is a balance between my tasks and my authority.", "I experience job satisfaction in this workplace." "There is no gender discrimination in recruitments in my institution.", "There is no gender discrimination in promotions in my work place.", "I think that women and men are given equal opportunities in society.", "If the economic power of the man is enough, it is better that the woman does not work.." and "It is the man's fundamental duty to make a living for the house."

\section{Conclusion}

The perceptions and views of employees about their jobs and the satisfaction they get from their job has a significant place in the development of societies and corporation/institutions. Likewise, there are important decuctions made in recently developing modern management approaches that employees are the locomotives of a corporation or institution. Being a social entity, human beings, as well as workers, have a multi-dimensional character or structure, rather than just mechanical, which could be influenced from a large number of factors. In this respect, for centuries gender perceptions have always been the reason for and origin of the emergence of various meanings and associations by getting influenced from cultural, traditional and social factors in almost all societies. As is in most cultures, in work culture, social gender perceptions have been a determinant variable in terms of business flow, distribution of tasks and responsibilities, career, promotion and payment policies. In this regard, the viewpoints and approach of employees at universities, which are the centers of free and critical view, about this concept and thus about job satisfaction and their institution form an important ground for the vision of other fields, as well. To this end, relevant hypotheses are tested with supportive findings in a study conducted at the sample of Erciyes University that job satisfaction has a linear impact on corporate/institutional reputation, social gender perceptions have a say on job satisfaction and that there would certainly be significant differences between female and male employees in regards to their relevant perceptions. On the other hand, the views and approaches of Erciyes University employees regarding the concepts analyzed in the study are positive and promising. Similarly, there is a relatively low tendency to opt for well-established stereotypes/customs in gender and job satisfaction with most employees not supporting the stereotypic beliefs regarding social gender and in-equality between men and women. Furthermore, employees demonstrated a positive stance regarding management, task-authority distribution, promotion and social opportunities in their universities with no serious indiciation of gender discrimination. It is certainly possible for these opinions and judgments to change from time to time and this also creates a limitation for the study. Although previous studies highlight that there was a more traditional stance in this issue on the part of universities, this study 
Tanyeri Mazıcı, E., Gölgeli, K. (2017). Job satisfaction in terms of social gender equality in employees and its effect on the corporate reputation: The sample of ERU academicians. International Journal of Social Sciences and Education Research, 3(2), 508-518.

could be said to attain a significance as it provides the opportunity to make comparisons between the findings of past, present and future studies. In conclusion, the existence of a more conscious society and business world, and more importantly a more sensitive and caring management in this respect will bear a better management and reputation thus paving the way for further accomplishments.

\section{References}

Akdağ, M. (2010). Insan Kaynaklarl ve Halkla İlişkiler. Konya: Literatürk Press.

Barnett, M.L., Jermier, J. M. \& Lafferty B.A. (2006). Corporate Reputation: The Definitional Landscape. Corporate Reputation Review, 9(1), 26-38.

Baybora, D. (2011). Kurumsal İtibar ve Çalışanlar. In A.Nurhan Şakar (Eds.), Kurumsal İtibar ve Paradigmalar, (pp. 101-124). İstanbul: Beta Press.

Büyüköztürk, Ş., Çakmak, E., Akgün, Ö., Karadeniz Ş., and Demirel, F., (2010). Bilimsel Araştırma Yöntemleri. Ankara: Akademi Press.

Camara, N. Z. (2011). Identity, Image and Reputation., In Sabrina Helm, Kerstin Liehr Gobbers, Christopher Storck (Eds.), Reputation Management, (pp. 47-58). Berlin Heidelberg, Springer.

Chun, R. (2005), Corporate Reputation: Meaning and Measurement. International Journal of Management Reviews, 7 (2), 91-109.

Çekmecelioğlu, H. G. \& Dinçel, G. (2013). Çalışanların İş Tutum ve Davranışlarının Kurumsal İtibar Üzerindeki Etkileri. Elektronik Sosyal Bilimler Dergisi- Electronic Journal of Social Sciences, 12(47), 125-139.

Connell, R.W. (1998). Toplumsal Cinsiyet ve İktidar. İstanbul: Ayrıntı Press.

Dursun, Ç., Öztürk R., Evliyaoğlu, G., Becerikli, S. Y., Poyraz, B., \& Memiş, E. (2013). Ankara Üniversitesi Toplumsal Cinsiyet Eşitliği İklimi ve Kültürü Araştırma Raporu. Ankara Üniversitesi Toplumsal Cinsiyet Eşitliği İklimi Ve Kültürü Araştırması. Retrieved from (http://kasaum.ankara.edu.tr/files/2013/02/GENOVATE-Raporu.pdf).

Eren, E. (1998). Örgütsel Davranışv ve Yönetim Psikolojisi. İstanbul: Beta Press.

Fombrun C. (1996). Reputation. Boston:Harvard Business School Press.

Fombrun, C. and van Riel, C. B. M. (2003). Fame and Fortune. New Jersey: Prentice Hall.

Giddens, A. (2005). Sosyoloji. Ankara: Ayraç Press.

Gobbers, L. K. and Storck C. (2011). How to Approach Reputation. In Sabrina Helm, Kerstin Liehr Gobbers, Christopher Storck (Eds.), Reputation Management, (pp 27-30). Berlin Heidelberg, Springer.

Hon, L. C.; Gruning, L. A. and Dozier, D. M. (2005). Halkla İlişkiler ve Kadın: Sorunlar ve Fırsatlar. In James E.Grunig (Eds.), Halkla İlişkiler ve İletişim Yönetiminde Mükemmellik, (pp.441-462). İstanbul, Rota Press.

Kadıbeşegil, S. (2013). İtibar Yönetimi. İstanbul: Media Cat Press.

Kahraman, L., Kahraman, B. A., Ozansoy, N., Akıllı, H., Kekillioğlu, A., \& Özcan, A. (2014). Nevşehir Hacı Bektaş Veli Üniversitesi Toplumsal Cinsiyet Algısı Araştırması. Turkish Studies - International Periodical For The Languages, Literature and History of Turkish or Turkic 9(2), 811-831.

Keller, F. (2007). Toplumsal Cinsiyet ve Bilim Üzerine Düşünceler. İstanbul: Metis Press. 
Tanyeri Mazıcı, E., Gölgeli, K. (2017). Job satisfaction in terms of social gender equality in employees and its effect on the corporate reputation: The sample of ERU academicians. International Journal of Social Sciences and Education Research, 3(2), 508-518.

Kocacık, F. \& Gökkaya, V. B. (2005). Türkiye'de Çalışan Kadınlar ve Sorunları. C.Ü. İktisadi ve İdari Bilimler Dergisi, 6(1), 195-219.

Marshall, G. (2005). Sosyoloji Sözlüğ̈̈. Ankara: Bilim ve Sanat Press.

National Action Plan, (2008, September, 01) Retrieved from http://www.huksam.hacettepe.edu.tr/Turkce/SayfaDosya/TCEUlusaleylemplani.pdf

Negiz, N., Oksay, A. \& Akman, E. (2011). İşe Bağlılık ve İşten Tatmin Açısından Cinsiyet ve Sektörel Farkl11ık: Kamu ve Özel Sektör Kuruluşlarında Karşılaştırmalı Bir İnceleme (Isparta Örneği). Süleyman Demirel Üniversitesi Sosyal Bilimler Enstitüsü Dergisi- Journal of Süleyman Demirel University Institute of Social Sciences, 2(14), 207-229.

Oakley, M. J. (1998). Kadın ve Eşitlik. İstanbul:Pencere Press.

Özkaplan, N. (2013). Kadın Akademisyenler: Cam Tavanlar Hâlâ Çok Kalın!. Kadın Araştırmaları Dergisi, 2013(12), 1-23.

Peltekoğlu, F.B. (2009). Halkla İlişkiler Nedir. İstanbul: Beta Basım Press.

Poyraz, B. (2013). Akademi Kadınların Cenneti mi? Ankara Üniversitesi Örneği. Ankara Üniversitesi Sosyal Bilimler Enstitüsü Dergisi, 4(2), 1-18.

Reed, E. (2003). Bilim ve Cinsiyet Ayrımı. İstanbul: Payel Press.

Robbins, S. P. \& Judge, T. A. (2012). Essentials of Organizational Behavior. USA: Pearson.

Sabuncuoğlu, Z. (2004). İşletmelerde Halkla Illişkiler. Bursa: Alfa Aktüel Yayınları.

Serinkan, C. \& Bardakçı, A. (2007). Pamukkale Üniversitesi’nde Çalışan Öğretim Elemanlarının İş Tatminlerine İlişkin Bir Araştırma. Selçuk Üniversitesi Karaman IIBF Dergisi, 12(9), 152-163.

Turban, D.. B. and Cable, D. M. (2003). Firm Reputation and Applicant Pool Characteristics. Journal of Organizational Behavior, 24(6), 733-751.

Türk, M. S. (2007). Örgüt Kültürü ve İş Tatmini. Ankara: Gazi Press. 